\title{
PERGAMUS DAN IMPERIAL CULT
}

\author{
Hermawan \\ Sekolah Tinggi Teologi Amanat Agung \\ Jalan Kedoya Raya No. 18, Kedoya Utara, Kebon Jeruk, Jakarta Barat 11520 \\ hermawancherish@gmail.com
}

\begin{abstract}
ABSTRAK: Bukti-bukti imperial cult sudah ada secara umum dalam literatur-literatur teologi dan biblika. Namun, hadir kajian-kajian baru yang menyatakan bahwa tidak adanya hubungan antara imperial cult dengan penganiayaan orang Kristen. Meresponi kajiankajian baru tersebut, tulisan ini akan menekankan bahwa kota Pergamus adalah pusat imperial cult di Asia Minor, dan memiliki hubungan dengan penganiyaan orang-orang Kristen. Fakta bahwa Pergamus menjadi pusat imperial cult di Asia Minor ditunjukkan oleh kehadiran pemerintah Roma di kota tersebut dengan pembangunan kuil-kuil kultus kaisar, gelar neokoros yang disandang oleh Pergamus sebanyak tiga kali berturut-turut, dan melalui bukti-bukti internal dalam Wahyu 2:12-17 yaitu gambaran tahta iblis dan Antipas, Bileam dan Nikolatian serta perang dan kemenangan yang merujuk pada unsur-unsur yang berkaitan dengan kultus kaisar. Artikel ini menerapkan studi literatur yang meliputi analisa teks Alkitab dan kepustakaan.
\end{abstract}

Kata-kata kunci: penyembahan, penganiayaan, pergamus, wahyu

\section{PERGAMUM AND IMPERIAL CULT}

\begin{abstract}
The evidences of the imperial cult are generally available in theological and biblical literature. However, some new studies have appeared that suggest there is no connection between the imperial cult and the persecution of Christians. Responding the new studies, this writing will emphasize that the city of Pergamum is the center of the imperial cult in Asia Minor, and it has connection with the persecution of Christians. The fact that Pergamum became the center of the imperial cult in Asia Minor is demonstrated by the presence of the Roman government in the city by the construction of the emperor's cult shrines, the title of neochoros held by Pergamum three times in a row, and through internal evidences in Revelation 2:12-17 namely the description of the throne of the devil and Antipas, Balaam and Nikolatian, as well as wars and victories which refer to the elements related to the emperor cult.
\end{abstract}

Keywords: cult, persecution, pergamum, revelation

\section{PENDAHULUAN}

Ada hubungan antara imperial cult (Naylor, 2010, p. 208) ${ }^{1}$ atau penyembahan kaisar dan penganiayaan orang Kristen pada abad pertama. Para sarjana ada yang tidak setuju dengan pernyataan tersebut, khususnya G. E. M. Ste. Croix. Sebagaimana dituliskan oleh Cukrowski, Croix berpendapat bahwa faktor penyembahan kaisar itu hampir sama sekali tidak memiliki peran dalam penganiayaan orang-orang Kristen
(Cukrowski, 2003, p. 55). Tetapi Laurie Guy, dalam bukunya Introducing Early Christianity menyatakan bahwa ada 3 bukti, salah satunya adalah dalam Kitab Wahyu, yang menunjukkan hubungan ini (Guy, 2004, pp. 63-64). Hal ini juga senada dengan pandangan Donald Jones, memiliki pandangan yang sama dengan Guy, bahwa hubungan keduanya sangat kuat. Bahkan ia menyebutkan bahwa dalam Wahyu 1-3 merupakan gambaran penganiayaan yang terjadi di 
bawah Kaisar Domitian, di Asia Minor (Cukrowski, 2003, p. 55). ${ }^{2}$ Cukrowski dalam artikelnya menunjukkan bahwa ada buktibukti dari penyembahan kaisar yang tersebar di 4 kota dalam Kitab Wahyu, yaitu Efesus, Smirna, Pergamus dan Laodikia (Cukrowski, 2003, p. 56). Tiga kota yang memiliki kuil penyembahan kepada Domitian, adalah Efesus, Laodikia dan Pergamum (Cukrowski, 2003, p. 61).

Pandangan Guy dan Jones memberikan sebuah perhatian yang lebih spesifik dalam meneliti mengenai hubungan penyembahan kaisar dan penganiayaan orang Kristen. Keduanya menyinggung mengenai Kitab Wahyu dan Asia Minor. Lebih jauh, S. R. F. Price menyatakan "The cults of the Roman emperor performed by the Greek cities of Asia Minor during the first three centuries A.D" (Price, 1998, p. 1). Hal ini menunjukkan bahwa sebenarnya Asia Minor memiliki peran yang besar dalam perkembangan penyembahan Kaisar dan hubungannya dengan penganiayaan orangorang Kristen pada abad pertama. Kota-kota yang berada di Asia Minor tersebut juga disebutkan dalam Kitab Wahyu. Ada tujuh surat yang ditujukan kepada ketujuh jemaat di tujuh kota. Kota-kota tersebut adalah Efesus, Smirna, Pergamus, Tiatira, Sardis, Filadelpia, dan Laodikia. Kota Pergamus adalah kota yang dihormati dibandingkan dengan kotakota lain di Asia, bukan hanya sebagai ibu kota dari seluruh provinsi tetapi juga sebagai pusat ritual penyembahan kaisar (Ramsay, 1994, p. 212).

Terkait dengan hal di atas, makalah ini akan menunjukkan bukti-bukti yang ada di dalam Wahyu 2:12-17 mengenai hubungan penyembahan kaisar dengan penganiayaan orang Kristen pada abad pertama, yang berkaitan juga kota Pergamus. Teks ini merupakan teks yang secara eksplisit menyebutkan nama Kota Pergamus dalam konteks penganiayaan jemaat di Pergamus.

Oleh karena itu, makalah ini akan menelusuri latar belakang kota Pergamus dan perannya dalam dunia abad pertama yang berkaitan dengan penyembahan kaisar. Makalah ini akan menyoroti bagian dari Wahyu 2:12-17 dengan lebih rinci dengan pendekatan sosio-historis.

\section{METODE}

Artikel ini menerapkan studi literatur yang meliputi analisa teks Alkitab dan kepustakaan. Metode yang diterapkan melihat teks yang diteliti dari sudut pandang latar belakang sosial dan historis. Teks-teks tersebut akan dikaitkan dengan kondisi atau konteks sosio-historis masa penulisannya. Metode ini akan melibatkan kajian terhadap sumber pustaka yang berkaitan dengan tema dari makalah ini. Beberapa literatur utama adalah tulisan dari Richard Bauckham, William M. Ramsay dan S.R.F. Price yang berkaitan dengan kitab Wahyu. Selain literatur dari ketiga tokoh tersebut, makalah ini juga menggunakan hasil-hasil penelitian biblika yang berkaitan dengan sejarah, arkeologi, dan teologi, yang berhubungan dengan judul dan topik yang dibahas.

\section{HASIL PEMBAHASAN}

\section{Kota Pergamus dan Kultus Kaisar}

Pergamus signifikan sebagai kota yang memiliki peranan dalam praktik penyembahan kaisar pada abad pertama dalam hubungan dengan kitab Wahyu. Pergamus dikenal sebagai Koinon of Asia, yang berperan sebagai provinsi pusat pemerintahan 
Romawi di Asia kecil (Botha, 1988, p. 93) pada abad pertama. ${ }^{3}$

Kota Pergamus, merupakan kota yang penting dalam abad pertama (Ramsay, 1994, p. 131). Kota ini pernah menjadi tempat pemerintahan dinasti Attalid sekitar tahun 283-129 SM (Tabbernee, 2014, p. 281). Pada masa pemerintahan Roma kota ini menjadi ibu kota pemerintahan Roma untuk wilayah Asia (Tabbernee, 2014, p. 281) Raja Attalus 1 menjadi penguasa pertama di Asia, setelah ia mengalahkan Gaul. Kemenangannya itu menjadi peringatan dengan memberikan gelar padanya sebagai raja penyelamat. Kejadian ini juga menjadi awal perkembangan dari sebuah seni ukir, monumen pertama pada waktu itu didedikasikan untuk Zeus Soter. Kemungkinan besar hal ini, adalah awal munculnya kultus penguasa atau penyembahan kaisar (Hemer, 1986, p. 80). Pada masa Attalus III, Pergamus dikuasai oleh pemerintah Roma. Pergamus menjadi pusat kekuasaan selama kurang lebih 4 abad, kemungkinan besar pada masa yang sama ketika Yohanes menulis tujuh surat kepada tujuh jemaat (Ramsay, 1994, p. 207).

Pada perkembangan berikutnya, melalui berbagai krisis dan pergantian pemimpin, Pergamus tidak lagi menjadi ibukota untuk Asia, tetapi perannya dalam bidang keagamaan sangat kuat. Pada tahun $29 \mathrm{M}$, kuil yang didedikasikan untuk kaisar Agustus dan Roma didirikan, kaisar Agustus diberikan gelar sebagai Yang Ilahi. Gelar ini menjadi sesuatu yang krusial bagi Roma dan Agustus, setiap orang yang tidak menyembah Agustus maka dikenakan sangsi yang berat (Tacitus \& Barrett, 2008, p. 156). Selain di Pergamus, kuil Agustus juga didirikan di Nikomedia. Pertumbuhan kultus itu menjadi sebuah gerakan yang sangat cepat diikuti oleh kota-kota lain. Kuil Agustus dan Aesculapius yang didirikan di Pergamus ini menjadi prototype bagi kuil-kuil yang didirikan di kekaisaran Roma (Evans, 2014, p. 87). Ini sebuah menjadi sebuah kewajaran bagi kotakota Asia pada waktu itu, karena dengan mendirikan kuil atau mengadakan festival bagi para penguasa maka mereka akan mendapatkan bantuan dari penguasa tersebut (Evans, 2014, pp. 78-79).

Selain kuil Agustus, di Pergamus juga ada kuil bagi Dewa Zeus dan Kaisar Trajan. Bahkan dalam kuil itu terdapat patung Trajan seperti Zeus, yang memegang petir ditangannya. Bahkan kaisar-kaisar lain pun seringkali digambarkan dengan cara yang sama di dalam kuil-kuil di Asia Minor. Meskipun Price menyatakan bahwa hal tersebut sesuatu yang dikritisi pada masa itu tetapi hal ini tidak dalam dipungkiri sebuah kenyataan bahwa kaisar-kaisar tersebut dikultuskan (Price, 1998, pp. 183-184).

Penyembahan kaisar ini tidak hanya bicara mengenai kuil, akan tetapi juga unsurunsur dari penyembahan itu sendiri. Unsur yang penting di dalam penyembahan kaisar itu sendiri adalah persembahan korban. Price menyimpulkan bahwa orang Yahudi dapat menyesuaikan diri dengan baik, akan tetapi orang Kristen mengalami kesulitan. Bagi orang Yahudi, mereka memiliki kebiasaan yang sama mempersembahkan korban atas nama kaisar (Price, 1998, p. 220). Sedangkan bagi orang Kristen, ini adalah masalah utama, karena persembahan korban di Bait Suci sudah digantikan dengan pengorbanan Kristus di atas kayu salib. Inilah penyebab penganiayaan terhadap orangorang Kristen. Meskipun Price menyatakan bahwa korban terhadap kaisar itu sebuah pengecualian. Persembahan korban terhadap dewa-dewa lebih utama, dibandingkan dengan persembahan korban terhadap kaisar (Price, 1998, p. 221). 
Penemuan koin-koin Pergamus yang berfungsi sebagai penghormatan pada ritual penyembahan Kaisar dalam kuil Neokoros, memperkuat kehadiran penyembahan kaisar di Pergamus. Neokoros artinya adalah "penjaga kuil", yang merupakan sebuah bentuk penghargaan kepada kota-kota tertentu oleh senat Roma atau kaisar. Pergamus mendapatkan penghargaan ini sebanyak 3 kali yaitu pada masa pemerintahan Kaisar Agustus, Trajan dan Caracalla (Zając, 2017, p. 62). Pada masa Kaisar Agustus, terjadi pada tahun 29 M (Zając, 2017, p. 63). Pada masa Kaisar Trajan, terjadi pada tahun 113/114 atau 114/115 M (Zając, 2017, p. 66). Pada masa Kaisar Caracalla, terjadi pada tahun 213/214 M. Bahkan gambar kuil pada pemerintahan kaisar-kaisar lain (termasuk Nero, Domitian dan Hadrian) pun ditemukan pada koin-koin dari Pergamus. Hal ini menunjukkan peran penting kota ini sebagai kota penyembahan Kaisar (Zając, 2017, pp. 6465). Zając (2017, p. 69) menyimpulkan penelitiannya mengenai Neokoros Pergamus ini dengan menyatakan:

Pergamum was a very important city whose inhabitants used, and had tried obtain the title of neokoros several times. This city represented a very special status, because the title had been granted three times and was emphasised in epigraphic and numismatic sources.

\section{Wahyu 2:12-17}

Konteks peran Pergamus yang menyandang gelar sebagai penjaga kuil dan pusat penyembahan Kaisar di Asia Kecil adalah sesuatu yang sangat berkaitan dengan konteks Kitab Wahyu, yaitu perlawanan terhadap sistem keagamaan kerajaan Romawi yang berlawanan dengan iman Kristen, khususnya praktik penyembahan kaisar. Bagian
Wahyu 2:12-17 merupakan bagian yang termasuk di dalam dua bagian Kitab Wahyu yang secara biblis memberikan indikasi kuat mengenai penyembahan kaisar. Dua bagian tersebut adalah Wahyu 2-3 dan Wahyu 1319. Friesen melihat bahwa ada upaya persuasi Yohanes supaya jemaat tidak berpartisipasi dalam penyembahan kaisar (Friesen, 2005, p.367).

Ada tiga pandangan dari para sarjana mengenai tahun penulisan dari Kitab Wahyu. Pandangan pertama, kebanyakan dari sarjana setuju bahwa Kitab Wahyu ditulis pada masa pemerintahan Kaisar Domitian pada tahun 81-96 M. Menurut pandangan kedua, Kitab Wahyu ditulis pada masa pemerintahan Kaisar Nero, yaitu di antara tahun 64-70 M. Pandangan ketiga, menganggap penglihatan yang dialami Yohanes ini, terjadi pada masa pemerintahan Nero lalu kemudian dituliskan pada masa pemerintahan Domitian (Thomas \& Macchia, 2016, p. 27). Walaupun ada perbedaan pandangan, tetapi ada fakta yang tidak bisa dihindari bahwa kedua kaisar tersebut telah melakukan penganiayaan terhadap orang-orang Kristen. Nama Nero disandingkan dengan Domitian (dianggap sebagai Nero kedua) untuk menyatakan bahwa kedua kaisar ini bertanggung jawab terhadap penganiayaan yang terjadi pada orang-orang Kristen pada zaman itu. Hal ini ditemukan dalam tulisan Eusebius (1980, p. 391), The Ecclesiastical History, yang menyatakan:

\begin{abstract}
The only emperors who were persuaded by malicious men to slander our teaching were Nero and Domitian, and from them arose the lie, and the unreasonable custom of falsely accusing Christians.
\end{abstract}

Selain Nero dan Domitian, Kaisar Trajan juga merupakan kaisar yang mengadakan penganiayaan terhadap orang-orang 
Kristen. Bukti ini terdapat dalam surat dari Pliny kepada Trajan, yang berkaitan dengan bagaimana melakukan, mewawancarai dan membuat keputusan terkait dengan eksekusi orang-orang Kristen (Pliny, 2006, pp. 278279). Kaisar Trajan memberikan respons terhadap pertanyaan Pliny dalam suratnya, ia menyatakan (2006, p. 279):

You have followed the appropriate procedure, my Secundus, in examining the cases of those brought before you as Christians, for no general rule can be laid down which would establish a definite routine. Christians are not to be sought out. If brought before you and found guilty, they must be punished, but in such a way that a person who denies that he is a Christian and demonstrates this by his action, that is, by worshipping our gods, may obtain pardon for repentance, even if his previous record is suspect. Documents published anonymously must play no role in any accusation, for they give the worst example, and are foreign to our age.

Guy memberikan komentar terhadap pernyataan ini, bahwa orang-orang Kristen yang dibawa kepada Pliny berasal dari masa yang beragam. Ada yang baru menjadi Kristen selama 3 tahun, beberapa tahun dan bahkan ada yang sekitar 20 tahun. Menurut Guy (2004, p. 64), hal ini menunjukkan kecocokan dengan penganiayaan yang terjadi pada masa Domitian di Roma, namun juga dilakukan oleh pejabat-pejabat kekaisaran dalam wilayah-wilayah lokal.

\section{Tahta Iblis dan Antipas}

Dalam ayat 13 dikatakan bahwa Pergamus adalah "tempat tahta Iblis". Ramsay menghubungkan tahta iblis ini dengan gambaran dari koin pada masa Kaisar Caracalla. Koin tersebut menunjukkan gambar ular yang sedang melingkar pada sebuah pohon dan gambar kaisar pada sebelahnya. Sedangkan di tengah gambar Telesforus. Ramsay menyatakan bahwa ular dan kaisar, keduanya adalah tuhan (Ramsay, 1994, p. 207). Ramsay (1994, p. 215) menyimpulkan bahwa "Iblis" disini merupakan "sebuah kekuatan resmi yang menjadi lawan gereja." Hal ini juga dihubungkan dengan ayat 12, "pedang yang tajam dan bermata dua", iu gladii, yang dihubungkan dengan kekuasaan untuk menentukan hidup dan mati. Hal ini juga berkaitan dengan penggunaan kekuasaan dari pihak golongan atas yang diwakilkan dengan prokonsul wilayah di Pergamus (Ramsay, 1994, p. 214). Lebih jauh, Ramsay menyatakan bahwa ketika Yohanes menulis ketujuh surat kepada tujuh jemaat, pemerintah menyatakan posisinya melawan ajaran gereja. Iman orang Kristen diuji dengan kebijakan pemerintah Roma, di Pergamus, mengenai ketentuan memberikan korban pada ritual penyembahan kaisar. Jika mereka tidak memberikan korban atau turut dalam penyembahan ini, maka mereka akan dihukum mati dan dianggap sebagai musuh negara (Ramsay, 1994, p. 215). Pandangan ini tentu sangat cocok dengan penelitian Zając mengenai nekoros, Pergamus menjadi kota pusat penyembahan Kaisar, di Asia. Pergamus mendapatkan penghargaan neokoros (penjaga kuil kaisar atau dewa) sebanyak tiga kali dalam tiga masa pemerintahan dari tiga kaisar yang berbeda.

Selain itu, dari sisi teologi Kitab Wahyu itu sendiri pun sesuai. Teologi Kitab Wahyu secara umum, memiliki keunikan tersendiri. Teologi Kitab Wahyu, tidak hanya teosentris tetapi juga bertalian dengan penyembahan kepada Yesus. Richard Bauckham (1993, p. 26) menyatakan bahwa ada pola pernyataan diri Allah yang diikuti dengan pernyataan diri 
Yesus Kristus. Contohnya ada dalam Wahyu 1:8, pernyataan diri Allah "Akulah Alfa dan Omega" kemudian diikuti oleh pernyataan Kristus "Akulah Yang Awal dan Yang Akhir". Hal ini juga terulang dalam Wahyu 22:6, pernyataan Allah, dan ayat 13 pernyataan Kristus. Lebih jauh, Bauckham (1993, p. 28), menemukan pernyataan yang menunjuk pada Allah sebagai penguasa tunggal. Hal ini terdapat dalam Wahyu 1:4, 8; 4:8; 11:17; 16:5, Allah adalah Seorang yang akan telah ada, yang sekarang dan yang akan datang. Bauckham (1993, p. 30) menafsirkan bahwa Allah adalah kekal yang tidak terpisah dengan dunia tetapi hadir di tengah dunia dan umat-Nya. Hal senada juga disampaikan oleh Aune (1983, p. 280), ia menyatakan bahwa formula "Akulah..." merupakan sebuah pengungkapan diri, yang merupakan ciri khas dari sebuah perkataan nubuatan dari Perjanjian Lama. Hal ini sebuah bentuk perlawanan dari penyembahan kaisar yang begitu kuat di Pergamus dan kota-kota Asia Minor, khususnya kota Pergamus.

Relasi antara "tahta iblis" dan Antipas sebagai martir sangat berhubungan erat. Hemer (1986, p. 85) menyatakan bahwa jemaat di Pergamus tidak dapat melarikan diri untuk menghindari penganiayaan yang muncul di Pergamus. Penyebutan nama Antipas sebenarnya untuk menguatkan kondisi bahaya yang dialami oleh jemaat Pergamus. Ramsay menambahkan bahwa penganiayaan sudah menyebarluas di Asia Minor. Hal ini ditunjukkan dengan adanya proses hukum yang sudah ditetapkan kepada Antipas. Koester (2014, p. 287) menyatakan "Later tradition pictured Antipas being interrogated by the Roman prefect and then placed in a hollow bronze bull, which was heated over a fire until he roasted to death (Acta Sanc. 2:3-5)" Penganiayaan pada masa tersebut bukan penganiayaan yang bersifat lokal tetapi sudah menyebarluas karena sudah ada ketetapan hukum yang diberlakukan (Ramsay, 1994, p. 218). Kata $\mu$ óprus yang muncul di bagian ini adalah kata kedua setelah 1:5. Pada 1:5 kata ini dipakai untuk menggambarkan Yesus sebagai Saksi setia, lalu muncul kembali di 3:14 dan 17:6. Hemer (1986, p. 86) menyatakan bahwa nama Antipas sebagai sebuah representatif historis yang kemudian merujuk kepada para martir atau saksi-saksi lain setelahnya. Penganiayaan yang dialami jemaat Pergamus tidak dapat dilepaskan dari latar belakang sejarah kota Pergamus sebagai kota Neokoros, penjaga kuil kultus. Latar belakang sejarah kota Pergamus yang menganut ideologi sistem kultus raja sebagai yang ilahi, maka ini sangat tepat untuk penyembahan kaisar (Hemer, 1986, p. 86). Hemer menggunakan argumentasi Deissmann mengenai "polemical parallelism" untuk menunjukkan kontras antara Kristus dan kaisar. Hal ini menunjukkan bahwa hubungan antara Tahta Iblis dan Antipas merujuk pada penyembahan kaisar (Hemer, 1986, p. 87). Jemaat Pergamus mengalami tekanan dari pemerintah Roma dan iman mereka ditantang untuk menghadapi konfrontasi langsung dengan praktik penyembahan kaisar.

Jadi penyebutan Tahta Iblis dan Antipas merupakan sebuah penekanan tersendiri untuk kota Pergamus, khususnya orang Kristen, bahwa kota Pergamus memang sumber penyembahan kaisar yang kuat.

\section{Bileam dan Nikolaus}

Bileam dan Nikolaus atau Nikolatian merupakan sebuah representasi dari latar belakang sejarah yang terjadi di Kota Pergamus. Kedua nama ini dihubungkan dengan keberadaan orang Yahudi di kota Pergamus, 
karena kedua nama ini memiliki unsur Yahudi yang kental. Bileam dihubungkan dengan tokoh Perjanjian Lama yang memberikan nasihat yang sesat kepada Balak dan menyarankan umat Israel memakan persembahan berhala dan terlibat dalam percabulan (Bilangan 31:6 bandingkan dengan Bilangan 25:1-2) (Hemer, 1986, p. 91). Sedangkan Nikolaus, sebenarnya tidak bisa dihubungkan dengan salah satu diaken di dalam Kitab Kisah Para Rasul 6, karena tidak ada keterangan lebih detail untuk menguatkan hubungan tersebut. Lalu sebenarnya apa yang bisa ditemukan dalam bagian ini terkait dengan penyembahan kaisar?

Pada bagian ini, kata kata perhatian. Kata ini sendiri berulang 3 kali di dalam pasal 2 yaitu 2:14,15 dan 24. Dua kali ditujukan kepada jemaat Pergamus dan satu kali ditujukan pada jemaat Tiatira. Frasa

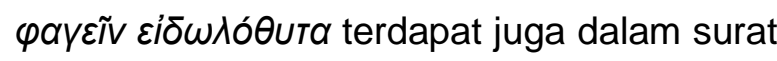
kepada jemaat Tiatira meskipun pada Perga-

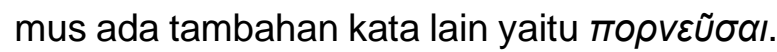
Dengan kata lain sebenarnya Tiatira dan Pergamus memiliki kesamaan pesan yang ingin disampaikan. Ramsay menjelaskan bahwa jemaat Pergamus mengalami tantangan karena berada dalam pola dan prinsip hidup Yunani yang mempengaruhi beberapa orang dalam jemaat. Orang-orang yang dipengaruhi tersebut memakan persembahan berhala yang dihubungkan dengan penyembahan kaisar (Ramsay, 1994, p. 220). Hemer juga memiliki pandangan yang sama, ia menghubungkannya dengan latar sejarah kota Pergamus yang mengharuskan semua warganya tunduk pada kaisar. Lebih lanjut, Hemer (1986, p. 92), menjelaskan bahwa sebenarnya para rasul sudah memutuskan agar jemaat-jemaat yang berasal dari bangsa-bangsa non Yahudi tidak boleh memakan persembahan berhala. Hemer (1986, p. 93) memberikan hipotesanya bahwa mungkin Balam dan Nikolatian memiliki kesamaan, yaitu keduanya adalah pengajarpengajar palsu.

Frasa yang penting yang perlu diper-

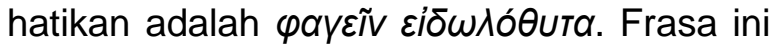
muncul dua kali dalam 2:14 dan 2:20. Penyembahan kaisar tidak lepas dengan agama sipil yang ada di Pergamus dan pendeta kultik berada pada posisi yang paling terhormat di kota (Ferguson, 2003, p. 212). Sama seperti penyembahan dalam agamaagama tradisional, ada persembahan korban dan biasanya hal ini dilakukan secara bersamaan. Hal ini ditunjukkan dengan penemuan altar korban untuk kaisar dan para dewa. Salah satunya dari altar itu ditujukan kepada Kaisar Agustus. Altar-altar ini seringkali dipakai bersamaan berfungsi sebagai altar persembahan bagi para dewa dan juga kaisar (Price, 1998, p. 216). Berkaitan dengan hal ini, Bauckham, memberikan pernyataan tegas atas dasar penemuan Price. la menyatakan "[A]t Pergamum, indicate a city decree instructing all citizens to provide their own altars for sacrificing outside their houses as the festival procession passed" (Bauckham, 2000 , p. 447). Dengan demikian, penyembahan kaisar tidak dapat dihindari oleh penduduk kota Pergamus, termasuk oleh orang Kristen.

Perihal mengenai persembahan dalam penyembahan kaisar ini juga sudah disinggung sebelumnya, bahwa persembahan korban merupakan salah satu unsur yang harus ada dalam penyembahan kaisar. Meskipun begitu Price (1998, pp. 218-219) menentang bahwa persembahan korban kepada dewa dan kepada kaisar dibedakan untuk menunjukkan mana kepada yang ilahi dan kepada manusia. Tetapi dengan adanya pertimbangan mengenai gambaran kaisarkaisar yang seringkali digambarkan seperti 
gambaran dewa-dewa, yang sudah dijelaskan sebelumnya, maka sangat kuat hubungannya bahwa memang ada usaha untuk mengikis batas-batas yang ilahi dan fana menjadi batas yang kabur. Hal ini juga didukung dengan peran pendeta tertinggi yang bukan hanya memimpin acara keagamaan tetapi juga acara publik lain. Pendeta juga biasanya mendapatkan daging dari korban persembahan sebagai penghormatan kepada dewa atau kaisar yang dihormati (Price, 1998, p. 217). Hal lain yang mendukung adalah bahwa seringkali pendeta ini juga memimpin acara-acara lain yang selalu diberikan sentimen agama kedalamnya (Ferguson, 2003, p. 212).

Berkaitan dengan hal ini, ajaran Bileam dan Nikolaus, yang dapat dirujuk jauh pada pandangan tegas Paulus dalam Surat 1 Korintus. Paulus melihat persembahan berhala merupakan sebuah imperial idolatry-istilah Ramsay (1994, p. 220) menghubungkan persembahan berhala dengan penyembahan kaisar-yang tidak boleh dilakukan oleh jemaat. Yohanes, menurut Ramsay, melihat Bileam dan Nikolatian sebagai kekuasaan yang bertentangan dengan ajaran Kristus. Sehingga pada jemaat Tiatira dan Pergamus, ia menunjukkan otoritas dan kewibawaan Kristus yang lebih berkuasa dibandingkan kaisar mana pun (Ramsay, 1994, p. 221).

Hal ini juga diperkuat dengan penyebutan Bileam dan Nikolatian memberikan sebuah tekanan tersendiri pada hubungan Pergamus sebagai kota pusat penyembahan kaisar, di Asia Minor. Ini menunjukkan kembali perhatian dan kewaspadaan terhadap apa yang terjadi di Pergamus. Surat pada jemaat lain tidaklah sebesar tekanan yang diberikan kepada jemaat di Pergamus. Hal ini juga ditunjukkan dengan penggunaan istilah perang yang akan dibahas dalam selanjutnya.

\section{Perang dan kemenangan}

Bauckham (2000, p. 210) menyatakan bahwa Kitab Wahyu adalah buku perang Kristen, yang memerangi musuh Allah dengan kuasa Allah dan serta peran aktif dari umatNya. Bauckham menunjukkan kemiripan Kitab Wahyu dengan dokumen Qumran, QM1 dalam hal tema yang diangkat yaitu mengenai peperangan mesianis dengan penggunaan teknis militeristik. Mesias datang untuk menghancurkan musuh-musuh-Nya. Istilah yang dipakai dalam QM1, menurut Bauckham, adalah istilah-istilah yang mudah dikenali oleh orang Yahudi pada zamannya (Bauckham, 2000, pp. 211-213). Lebih jauh Bauckham (2000, p. 213) menyatakan,

\begin{abstract}
John uses the metaphor of warfare in a general way for Christian witness and martyrdom, but that he takes up and reinterprets specific traditions about the messianic war, detailed exegesis is necessary.
\end{abstract}

la menafsirkan 3 bagian dalam Kitab Wahyu, yang menunjukkan adanya istilahistilah yang mendukung argumentasinya. Ketiga bagian tersebut adalah 5:5-6 (Mesias menaklukkan), 7:2-14 (Pasukan Mesianis), dan 14:1-5 (Anak Domba dan pasukan-Nya) (Bauckham, 2000, pp. 213, 215, 229). Hal ini

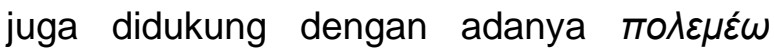
(perang), muncul sebanyak 6 kali dalam berbagai bentuk, yaitu dalam 2:16; $12: 7$ (2 kali); 13:4; 17:14; dan 19:11. Tema ini sebenarnya menunjukkan bahwa adanya ketegangan yang benar-benar hadir di jemaat Pergamus, berkaitan dengan memerangi penyembahan kaisar. Ini menjadi indikator bahwa pengaruh penyembahan kaisar di kota 
Pergamus tidak bisa dihindarkan oleh jemaat Pergamus.

Selain tema perang, tema kemenangan juga merupakan tema yang tersebar dalam

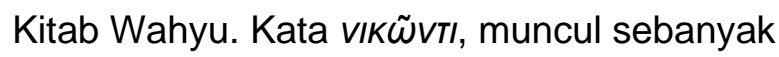
17 kali dalam Kitab Wahyu dan memiliki 9 bentuk dan berasal dari 15 ayat yaitu dalam Wahyu 2:7, 11, 17, 26; 3:5, 12, 21 ( 2 kali); 5:5; 6:2 (2 kali); 11:7; 12:11; 13:7; 15:2; 17:14; 21:7. Kata ini sebenarnya berasal dari akar kata vików yang berarti menang atau berkemenangan, bentuk lain dari víkn yang juga diartikan menang. Hal ini juga merupakan sebuah petunjuk lain yang menguatkan tema penyembahan kaisar yang kental dalam Kitab Wahyu, khususnya di Pergamus.

Koester memberikan rujukan yang menunjukkan bukti bahwa dalam kalender Filadelfia yang didedikasikan tahun tertentu untuk mengenang kemenangan Kaisar Agustus. Koester menyatakan, budaya Greko-Romawi penuh dengan tema kemenangan kaisar. Lebih jauh, Koester menjelaskan bahwa, "Dionysus was honored, perhaps in a temple or theater (I.Phil 1632), and the cult of Dionysus Kathegemon, the Leader, which had been associated with the rulers of Pergamum, was popular." Dionisius memiliki pengikut sendiri dan mereka diasosiasikan sebagai kultus agama (Koester, 2014, p. 322).

Bahkan Koester (2014, p. 322) menjelaskan Nike (víkn: kemenangan) memiliki kultus sendiri. Koester menyatakan,

Leading citizens served in traditional priesthoods, like that of Artemis (I.Phil1447), and the initiates of Dionysus Kathegemon had a religious association (1462). A household cult dating from the first century BCE included men and woman, free persons and slaves. This group formed under the auspices of
Agdistis, an Anatolian mother goddess, but those same worshipers also invoked the Hellenistic deities Zeus, Hestia, and the savior gods, along with Arete, or Virtue; Hygieia, or Health; Tyche Agathe, or Good Fortune; Agathos Daimon; Mneme; Charites, or Graces; and Nikē, or Victory. Members were to follow strict standards for ritual purity and moral conduct (I.Phil 1539).

Potret kemenangan yang kuat ini melatarbelakangi situasi surat kepada jemaat di Pergamus. Janji kemenangan dari Kristus disampaikan kepada jemaat Pergamus melawan ajaran sesat pengikut Bileam dan Nikolatian, yang merupakan representasi dari sistem penyembahan kaisar, yang diasosiasikan pada penyembahan berhala. Koester menambahkan bahwa Yohanes ingin menunjukkan kepada jemaat Pergamus bahwa Kristus mampu memberikan kemenangan kepada jemaat Pergamus. Jika dewan wilayah, pejabat Romawi, atau Kaisar, memiliki kuasa untuk membunuh Antipas, maka Kristus memiliki kuasa untuk membangkitkan Antipas dari kematian (Koester, 2014, p. 286). Dengan demikian jemaat Pergamus diarahkan untuk menyandarkan diri pada kekuatan Kristus yang mampu memberikan kemenangan dalam peperangan. Sama seperti Bauckham, Koester juga berada dalam satu kerangka pikir yang sama bahwa peran aktif dari umat Allah untuk memenangkan peperangan ini adalah dengan kesaksian iman mereka. Hal ini ditunjukkan oleh Koester dengan menyatakan bahwa Antipas merupakan contoh bagaimana seharusnya jemaat Pergamus berperan aktif dalam peperangan. Koester (2014, p. 294) menyatakan "If Antipas was put to death for his faith, Christ's judgment is the opposite: He calls Antipas a faithful 
witness, who exemplifies what it means to 'conquer' (2:13; 12:11)."

Upah dari kemenangan untuk peran aktif dalam peperangan pun disampaikan untuk memberikan antithesis terhadap praktik penyembahan berhala. Pada bagian 2:17, disebutkan bahwa setiap orang yang menang akan diberikan "manna yang tersembunyi" dan "batu putih". Gambaran "manna" ini menjadi sebuah alusi dari kisah bangsa Israel yang berada di padang gurun (Kel. 16:32-34). Bangsa Israel makan "manna" selama 40 tahun di padang gurun. Tuhan memerintahkan agar ada "manna" yang disimpan di dalam Tabut Perjanjian sebagai sebuah pengingat untuk generasi bangsa Israel berikutnya (Hemer, 1986, p. 94). Pada perkembangannya Tabut Perjanjian tersebut disembunyikan di bawah tanah, di Bait Suci Yerusalem-Hemer (1986, p. 95) merujuk pada 2 Makabe 2:4-7 untuk informasi ini. Pandangan ini mungkin benar, tetapi dengan pertimbangan kota Pergamus yang penuh dengan penyembahan kaisar dan nuansa-nuansa kultus Roma, maka korelasinya kurang dominan. Meskipun demikian unsur "manna" sebagai makanan itu tidak dapat dilepaskan. Konteks ayat ini dengan kaitan makan persembahan berhala, sangat kuat hubungannya dengan makan dalam pesta penyembahan kaisar. Sudah dibahas sebelumnya bahwa unsur penyembahan kaisar melibatkan persembahan korban termasuk korban binatang. Price menyatakan bahwa persembahan korban dibagikan kepada seluruh penduduk, salah satunya jug adalah roti. Price (1998, p. 229) menyebutkan dengan jelas mengenai hal ini, dengan menyatakan, “. . this might include a special combination of bread and meat, the meat presumably being obtained from the 'sacrifice of the emperors'..."
Hal ini sudah menjadi bagian dari kehidupan masyarakat, yang menunjukkan hubungan kota tersebut dengan para dewa dan kaisar dalam hubungan yang baik (Price, 1998, p. 230). Secara spesifik Price menjelaskan,

It is certainly true that many of the inscriptions of this period do lay great stress on the feasts and even allow those absent to receive money in place of food. The class of beneficiaries was also enlarged to include women and non-citizens. These general points apply equally to imperial sacrifices. Sometimes the feast alone is mentioned, as for an imperial birthday in a village or at provincial celebrations (1998, p. 229).

Price pun menyatakan bahwa hal ini menjadi fenomena yang mengakibatkan masalah besar bagi orang-orang Kristen. Hal ini dikarenakan orang-orang Kristen pada abad pertama dilarang untuk memakan persembahan berhala. Jadi dengan mengangkat tema "manna" kepada jemaat Pergamus, hal ini mengindikasikan bahwa jemaat Pergamus didorong untuk tidak terlibat dalam praktik seperti ini. Penyebutan "manna" adalah antitesis terhadap penyembahan kaisar untuk mengarahkan jemaat kepada Kristus, yang akan memberikan "manna". Hal ini juga senada dengan Hemer (1986, p. 95), ia menyatakan, "... the heavenly feast will belong to those who now abstain from the imperial eidolothuta". Konsep perayaan pesta makan besar bersama Kristus sudah cukup dikenal oleh gereja abad pertama. Wahyu 3:20-21 (bdk. 19:9, undangan perjamuan makan) juga menyinggung tentang hal ini, konsep makan bersama dikaitkan dengan konsep memerintah bersama Kristus (Thomas \& Macchia, 2016, p. 324). Itulah gambaran kemenangan yang dijanjikan Kristus kepada jemaat di Pergamus. 
Selain "manna", upah kemenangan itu juga berupa batu putih. Batu ini merujuk kepada tessera atau token yang merupakan tiket masuk ke sebuah perjamuan makan di Pergamus. Hal senada juga dinyatakan oleh Brent (1999, p. 183), bahwa tiket ini juga berfungsi sebagai tanda pembayaran untuk memasuki persembahan korban dalam penyembahan kaisar. Brent (1999, p. 183) lebih jauh menyimpulkan hubungan batu ini dengan memasuki liturgi dari sebuah penyembahan kaisar, dalam hal ini berkaitan erat dengan masa Domitian, di kuil Dionisius. Pada batu itu tertulis nama dari orang yang memilikinya. Nama ini, menurut Brent, ditulis dalam bentuk cryptogram; nama diubah menjadi bilangan. Brent memberikan bukti mengenai grafiti dari seseorang yang mengingat seseorang yang dikasihinya melalui sebuah bilangan. Lebih spesifik Brent (1999, pp. 184-185) memberikan bukti grafiti dari seorang bernama Amerimnos mengingat kekasihnya Harmonia, yang namanya direpresentasikan dengan bilangan 45 .

Batu putih yang terukir nama sebagai tanda masuk ke sebuah perjamuan makan penyembahan kaisar, merupakan sebuah bentuk kontra budaya. Brent (1999, p. 185) kemudian mengaitkan batu putih sebagai simbolisme dari baptisan. Meskipun, ini sebuah penafsiran yang terlalu jauh, namun poin utama Brent (1999, p. 185) sebenarnya adalah fungsi dari batu putih itu sendiri sebagai akses masuk perjamuan makan bersama Kristus, yang bertentangan dengan perjamuan makan persembahan berhala dari penyembahan kaisar. Brent memakai istilah cultic parallelism, untuk menunjukkan adanya unsur-unsur penyembahan kaisar yang ingin ditentang di dalam bagian ini.

Jadi dapat diringkaskan bahwa secara internal pun ada jejak-jejak yang bisa dilihat sebagai sebuah penolakan tegas terhadap penyembahan kaisar di dalam surat kepada orang-orang Kristen di Pergamus. Gambaran perang dan kemenangan yang digambarkan merupakan sebuah kemenangan di dalam konteks orang-orang Kristen Pergamus menikmati perjamuan besar bersama Kristus dan memerintah bersama Kristus. Hal ini juga menunjukkan adanya pengaruh penyembahan kaisar di Pergamus.

\section{SIGNIFIKANSINYA DALAM MEMBACA KITAB WAHYU}

Pembahasan yang sudah diuraikan di atas memberikan sebuah signifikansi logis bahwa penganiayaan terhadap orang-orang Kristen karena di bawah tekanan penyembahan kaisar merupakan sebuah kenyataan biblis dan historis. Hal ini memberikan sumbangsih yang besar terhadap bagaimana seseorang membaca Kitab Wahyu. Konteks penganiayaan jemaat dan penyembahan kaisar merupakan dua konteks besar yang tidak dapat dihindarkan dalam membaca Kitab Wahyu.

Bukti-bukti yang telah disajikan dalam pembahasan merupakan sebuah indikator terkait relasi kedua konteks yang saling terkait satu dengan yang lain dalam pembacaan Kitab Wahyu. Penyembahan Kaisar merupakan sebuah praktik penyembahan berhala yang bertentangan dengan keyakinan iman Kristen. Tulisan Rasul Yohanes bukan hanya memberikan sebuah bentuk pertentangan terhadap praktik penyembahan berhala, tetapi juga memberikan bukti-bukti adanya praktik tersebut.

\section{KESIMPULAN}

Berdasarkan penelitian yang telah dilakukan di atas maka dapat disimpulkan bahwa Pergamus merupakan pusat penyembahan kaisar di Asia Minor pada abad pertama, dengan beberapa pertimbangan. Per- 
timbangannya adalah adanya kuil-kuil kaisar Romawi, yang paling dominan adalah Kaisar Agustus yang disandingkan dengan Kuil Zeus. Kuil-kuil tersebut juga erat kaitannnya dengan persembahan korban di atas altaraltar di kuil maupun altar kecil yang bersifat pribadi. Selain itu Pergamus juga mendapatkan tiga kali berturut sebagai neokoros (penjaga kuil kaisar) dalam masa pemerintahan tiga kaisar, Agustus, Trajan dan Caracalla, yang jarang dialami oleh kota-kota Asia Minor lainnya pada masa itu.

Selain itu pertimbangan lain adalah dari bukti internal dari bagian Wahyu 2:12-17,

\section{DAFTAR RUJUKAN}

Aune, D. E. (1983). Prophecy in Early Christianity and the Ancient Mediterranean World. Grand Rapids: Eerdmans.

Bauckham, R. (1993). The Theology of the Book of Revelation (1st edition). Cambridge: Cambridge University Press. . (2000). Climax of Prophecy: Studies on the Book of Revelation. Edinburgh: T\&T Clark.

Botha, P.J.J. (1988).God, Emperor Worship and Society: Contemporary Experiences and the Book of Revelation, 87-120.

https://journals.co.za/docserver/fullte $\mathrm{xt} /$ neotest $/ 22 / 1 / 253$.pdf?expires $=157$ $9932091 \& i d=i d \&$ accname $=$ guest $\&$ ch ecksum=DDBB1DF13B01D512BF84 E6967FD2C8C8

Brent, R. A. (1999). The Imperial Cult and the Development of Church Order: Concepts and Images of Authority in Paganism and Early Christianity Before the Age of Cyprian. Boston: Brill.

Cukrowski, K. (2003). The Influence of the Emperor Cult on the Book of Revelation. Restoration Quarterly 45, 51-64. yang memberikan gambaran-gambaran yang merupakan alusi dari penyembahan kaisar. Gambaran yang dianggap sebagai bukti-bukti penyembahan kaisar itu adalah tahta iblis dan Antipas, Bileam dan Nikolatian serta perang dan kemenangan, yang berkaitan dengan upah kemenangan yaitu manna yang tersembunyi dan batu putih. Bukti-bukti ini mengerucut pada sebuah kesimpulan bahwa Pergamus memang merupakan sebuah kota yang sangat dipengaruhi oleh penyembahan kaisar sehingga nampak dalam gambarangambaran yang disajikan oleh Yohanes dalam bagian ini.

Eusebius. (1980). The Ecclesiastical History (K. Lake, Trans.). Cambridge, Massachusetts: Harvard University Press.

Evans, R. (2014). A History of Pergamum: Beyond Hellenistic Kingship (Reprint edition). London: Bloomsbury Academic.

Ferguson, E. (2003). Backgrounds of Early Christianity (3rd ed.). Grand Rapids: Eerdmans.

Friesen, S. J. (2005). Satan's Throne, Imperial Cults and the Social Settings of Revelation. Journal for the Study of the New Testament 27(3), 351-373. https://journals.sagepub.com/doi/pdf/ 10.1177/0142064X05052510

Guy, L. (2004). Introducing Early Christianity: A Topical Survey of Its Life, Beliefs Practices. Downers Grove: InterVarsity Press.

Hemer, C. J. (1986). The Letters to the Seven Churches of Asia in Their Local Setting. Sheffield: JSOT Press.

Koester, C. R. (2014). Revelation: A New Translation with Introduction and 
Commentary. New Heaven: Yale University Press.

Naylor, M. (2010). The Roman Imperial Cult and Revelation. Currents in Research 8(2), 207-239. http://journals.sagepub.com/doi/10.11 77/1476993X09349160

Pliny. (2006). Complete letters (P. G. Walsh, Trans.). Oxford: Oxford University Press.

Price, S. R. F. (1998). Rituals and Power: The Roman Imperial Cult in Asia Minor. Cambridge: Cambridge University Press.

Ramsay, W. M. (1994). The Letters to the Seven Churches (Updated ed; M. W. Wilson, Ed.). Peabody: Hendrickson Publishers.

Tabbernee, W. (Ed.). (2014). Early Christianity In Contexts: An Exploration Across Cultures and Continents. Grand Rapids: Baker Academic.

\section{CATATAN AKHIR}

1 "'Roman Imperial Cult' and 'emperor worship' are used to refer to the honors offered to the Roman emperor, such as the construction of temples and altars, the offering of various kinds of sacrifice, the establishment of priesthoods, the attribution of certain qualities, and the use of various titles, that may be seen as having religious overtones" (Nolan, 2010, p. 208).

2 Cukrowski mengutip dari Jones "The Domitianic persecution extended into Asia Minor, including several cities mentioned in Revelation 1-3 which were, at this time, important centers of emperor worship."

3 "The temple of Roma and Augustus at Pergamum was the meeting place of the Koinon of Asia (Tac Ann 4.37) and centre for the provincial imperial cult for at least the first half of the first century."
Tacitus, C., \& Barrett, A. A. (2008). The Annals: The Reigns of Tiberius, Claudius, and Nero (1 edition; J. C. Yardley, Trans.). Oxford: Oxford University Press.

Thomas, J. C., \& Macchia, F. D. (2016). Revelation: The Two Horizons New Testament Commentary. Grand Rapids: Eerdmans.

Zając, B. (2017). Neokoroi: Propaganda of the Imperial Cult on the Coins of Pergamum During the Reigns of Augustus, Trajan, and Caracalla. In B. Zając, A. Jurkiewicz, P. Koczwara, \& S. Jellonek (Eds.), Pecunia Omnes Vincit: The Coins as an Evidence of Propaganda, Reorganization and Forgery (pp. 61-74). Krakow: Institute of Archaeology. Krakow: Jagiellonian University. 